\title{
Duel Effects of Ostracism at Work with Differing Regulatory Focus of Ostracized Workers: Affective Event Theory Application
}

\section{Anila Umar', Seerat Fatima ${ }^{2}$, Amna Hasnain ${ }^{3}$}

M.Phil. Scholar, Institute of Management Sciences, Bahauddin Zakariya University, Multan. Assistant Professor, Institute of Management Sciences, Bahauddin Zakariya University, Multan. Lecturer, Institute of Management Sciences, Bahauddin Zakariya University, Multan.

\section{A B S T R A C T}

In this study, we examined the effect of workplace ostracism on employee's eudaimonia at work. We also tested the serial mediating effect of felt sadness, extra role and/or ingratiatory behavior along with moderating effects of differing regulatory focus of employees. We examined this phenomenon through the lens of affective event theory. The data was collected from 291 public sector employees of Pakistan. For data collection, we used time lag and multi-rated survey technique. Data was analyzed through smart PLS software. Results indicated that sadness mediates the relationship between workplace ostracism and extra-role behavior and also mediates between ostracism and ingratiation at work. The result indicated that promotion focus antagonistically moderate the relationship between sadness and extra-role and prevention focus failed to moderate the relationship between sadness and ingratiation at work. Furthermore, results also indicated that extra-role behavior positively related to eudaimonia and ingratiation at work negatively related to eudaimonia at work.

Keywords: Ostracism at work, Sadness, Extra role behavior, Ingratiation at work, Eudaimonia at work, Employee regulatory focus, Affective event theory

\section{INTRODUCTION}

Individuals spend a large portion of their days at the work. The significance of maintaining harmonized relationship with one another cannot be ignored as it helps develop positive interactions between employees, which in turn impacts the job performance and satisfaction (Chung, 2015). In such situation, if someone comes across facing any hassle during routine interactions at work, it proves to be an emotional destruction in the way of effective work performance (Blackhart, Nelson, Knowles, \& Baumeister, 2009). 
One of such hassles is being intentionally ostracized from the coworkers, supervisors or even subordinates (Chang et al., 2019). Ostracism is the kind of rejection behavior at work. There are different kinds of ostracising behaviors found in literature. For instance, linguistic ostracism reflects "a scenario in which two individuals talk to each other or converse with each other in such a way that people around them are unable to understand" (Dotan-Eliaz, Sommer, \& Rubin, 2009, p. 364). On the other hand, social rejection reflects "when one individual tries to build and sustain a relationship with some other individual and the individual says no (atleast unconditionally)" (Blackhart, Nelson, Knowles, \& Baumeister, 2009, p.270).Finally, organizational shunning, “a planned exclusion of a person from a group" (Anderson, 2009, p. 36). In this research, we are taking the concept of ostracism experienced by the individuals at the moment when they perceive themselves intentionally being rejected from others at the workplace.

Previous studies identified many damaging outcomes of workplace ostracism such as decreasing levels of job satisfaction, organizational dedication, person organizational fit and organizational citizenship behavior (Chung, 2017; Ferris, Brown, Berry, \& Lian, 2008; Hitlan \& Noel, 2009) and increasing levels of counterproductive work behaviors such as aggression, harassment, and conflict (Chung, 2015). Although majority of the studies found some negative outcomes of ostracism, but it might not always be the case. There is the possibility of dual effects of the phenomenon. Difference in outcomes depends on some contextual or contingency variables (Mao, He, \& Yang, 2020). This study is designed to investigate dual effects of ostracism in which duality led by difference in regulatory focus of the individual experiencing it.

For testing and verifying the dual effects, we are using the lens of affective event theory. We followed the major premise of the theory that uplifts at workplace such as experienced ostracism would lead employees to evoke feeling of sadness. Sadness is a sensation which is felt by the person when he perceives that he is intentionally being deprived of his social need for connectedness (Li, Chen, Chen, Bai, \& Crant, 2019; Yohana, Lubis, \& Wibisono, 2018; Pihkala, 2018).

Major contribution of the study is extending the affective event theory by proposing dual effects of emotional triggers due to differing regulatory focus of the 
individuals. One of the proposed outcomes of triggered emotion is positive (extra role behavior) and other one is negative (ingratiatory behavior). Extra-role behaviors refer to the behaviors those extends the main job requirement and are discretionary in nature (Kiazad, Kraimer, \& Seibert, 2019). Extra-role behavior includes social behaviors that are beneficial for the organization and its constituents, such as effectively coordinating organizational activities and providing help to their coworkers to share their workload (Alnaimi \& Rjoub, 2019; Chen \& Li, 2019). On the other hand, ingratiation is described as pretending a positive outlook, including (1) gratifying or honoring (2) uniformity in opinion and behavior, (3) self-improvement, and (4) providing favors to others (Jones \& Jones, 1964).

Megan et al., (2008) in their study found that the negative effects of ostracism are pronounced and prolonged according to a difference in the regulatory focus of individuals (Kark \& VAN DIJK, 2019; Zhang, Zhang, Ng, \& Lam, 2019). Thus, this study examines the moderating effect of promotion focus between sadness and extra-role behavior and the moderating effect of prevention focus between sadness and ingratiation. To the best of our knowledge, no previous study has examined the moderating effects of regulatory focus theory on the concept of ostracism at work.

\section{LITERATURE REVIEW}

\subsection{Mediating Role of Sadness between Ostracism and Extra ole Behaviour}

As discussed in previous section, ostracism means ignoring an individual or a group at the workplace (Williams, 2001). There are different ways in which ostracism can happen i.e. repulsing a specific individual or groups, individuals snubbing other groups and individuals (Fiset \& Bhave, 2019; Liu, Kwan, Lee, \& Hui, 2013). The perception of being alone and worthless adversely impacts the individual's feelings and emotions (Wu, Yim, Kwan, \& Zhang, 2012). Feelings of worthlessness provoke feelings of sadness. Although literature attributes sadness as a negative emotion, but few studies identified positive outcomes of this negative emotion (Tyran, 2018). Sadness helps increase assessment accuracy, decrease credulity and enhances the individual's calmness in a way that they start paying more attention to the smallest details (Clark, Robertson, \& 
Young, 2019; Mccarthy, Berrin Erdogan, \& Bauer, 2019). The research conducted by Bonanno (2009) discovered sadness plays an important role in an individual's personal growth and development. The sad individuals tend to be more empathetic and considerate for the people around them. They tend to perform more of discretionary and volunteer works of goodness. They perform many tasks which are not the part of their job description. Thus, based on the above argumentation, we came across following hypothesized relationship.

$\boldsymbol{H}_{1}$ : Feeling of sadness will mediate the relationship between experienced ostracism and extra-role behavior of employees.

2.2. Moderating Role of Promotion Focus between Sadness and Extra role Behaviour

The regulatory focus of the individuals plays an important role for behaving in a specific way. Individuals with promotion regulatory focus are more inclined towards their growth and development (Higgins, 1996, 1997). They are highly motivated to obtain positive incentives (Lichtenthaler \& Fischbach, 2019; Zhang et al., 2019). Promotion focused individuals like to emulate the positive and successful role models (Lockwood, Marshall, \& Sadler, 2005). Previous studies found that individuals with promotion focus ends up behaving very positively than those who lacks promotion focus (Weber \& Bauman, 2019). Thus, we argue that the individuals feeling of sadness which is mainly triggered due to some negative event lead them to positive outcomes more when they have promotion focus than they do not, as they are more concerned about achieving success in life. Following this line of argument, we suggest the following hypothesis, $\boldsymbol{H}_{2}$ : Promotion focus will moderate the relationship between sadness and extra-role behavior. In such a way so the relationship can be stronger in case of promotion focus but weaker when there is no promotion focus of employees.

\subsection{Mediating Role of Sadness between Ostracism and Ingratiation at Work}

Ingratiation is a basic behavior strategy for content with ostracism (Williams \& Zadro, 2005). Ingratiation is a social behavior in which individuals attempt to ameliorate their attractiveness in society (Liden \& Mitchell, 1988). Ingratiation can help individuals to achieve their goals if it is enacted properly (Kim, LePine, Zhang, \& Baer, 2019; Long, 
2019; Shaheen, Bari, Hameed, \& Anwar, 2019). It helps providing a friendly environment at work for appropriate social interactions (Sirén et al., 2020; Zhao, Li, \& Shields, 2019).

Sadness similar to other emotions is assumed to activate combined intellectual and behavior qualities that mobilize the individuals to achieve their goals (Levenson, 1999). Sadness encourages individuals to keep away from the distress that arises due to relationship loss by practicing behaviors that promote good and positive relationships among individuals (Chang et al., 2019). However, sadness increased the desire for social connectedness especially when at first sadness was caused due to social loss (Gray et al., 2011). Based on the above discussion, we argue, if individuals feel sadness due to ostracism, they pretend in a way that make their impression better in the eyes of significant people around them, so we hypothesized the following relationship, $\boldsymbol{H}_{3}$ : Feeling of sadness will mediate the relationship between experience ostracism and ingratiation.

\subsection{The Moderating Role of Prevention Focus between Sadness and Ingratiation at Work}

Previous studies on regulatory focus theory indicated that the motivation of prevention-focused people to engage into positive tasks is to avoid punishment (Long, 2019; Shah, Higgins, \& Friedman, 1998). In addition, increased efforts of prevention focused individuals are harmonized with their intention to avoid failure to achieve their goals and to escape themselves from negative outcomes (Liberman, Molden, Idson, \& Higgins, 2001; Weber \& Bauman, 2019; Zhang et al., 2019).

In particular, individuals showing more prevention focus are more concerned about their personal safety and protection than the individuals with weak prevention focus (Bilgili, Campbell, O’Leary-Kelly, Ellstrand, \& Johnson, 2020; Shah et al., 1998). High prevention-focused employees are most likely to exhibit ingratiation for their safety purpose because they want to save themselves from any negative event so we suggest that prevention focus will moderate the relationship between sadness and ingratiation.

$\boldsymbol{H}_{4}$ : Prevention focus will moderate the relationship between sadness and ingratiation. In such a way that the relationship will be stronger in case of prevention focus but 
weaker when there is no prevention focus of employees.

\subsection{Extra Role Behavior and Eudaimonia at Work}

Eudaimonia is considered as a striving force behind growth and development of the individual in a virtuous way to help him attaining his life goal (Waterman, 1993). An underlying assumption behind eudaimonia is enhancing wellbeing of the individuals (McMahan \& Estes, 2011). Eudaimonic employees work for bigger purpose and work to contribute to society wellbeing (Runyan et al., 2019). Thus, eudaimonia determines the personal growth, development, purpose, experience, and significance of employees socially at work (Ryff \& Singer, 2008).

The excessive research on the outcomes of extra-role behavior emphasized on the co-operational aspects, which are analyzed at individual stages, and focus on benefits that augment the organization or group (Chen \& Li, 2019; Kiazad et al., 2019). Extra role behavior develops resources by satisfying human necessities, for instance, freedom and relationship (Bono et al, 2013). Experimental evidence concerning extra-role behavior postulates that it enhances participant affect by satisfying his demands of relationship and aptitude (Weinstein \& Ryan, 2010). Extra role behavior such as helping is connected with the conception of changing other's lives and receiving appreciation from others which further enhances the self-image of the individual involved (Bolino \& Grant, 2016; Kleine, Rudolph, \& Zacher, 2019). Thus, extra-role behavior is hypothesized to be positively related to eudaimonia.

$\boldsymbol{H}_{5}$ : Extra role behavior of an employee is positively related to eudaimonia at work.

\subsection{Ingratiation and Eudaimonia at Work}

Previous researches confirm that ingratiation may prove to be harmful to an actor (Chang et al., 2019; Kim et al., 2019; Shaheen et al., 2019). While showing ingratiating behavior, the individuals just want to escape themselves from failure outcomes. They become more social and start honouring their co-worker because they want to project themselves good in the eyes of their co-workers for avoiding the negative consequences in life (Kuykendall, Craig, \& Tay, 2020). Thus, their concern is not about the personal growth but to avoid any negative consequences (Hanke, Rohmann, \& Förster, 2019; Kim et al., 2019; Long, 2019). Eudaimonia is positively related to personal growth and 
development, but ingratiation is negatively associated with eudaimonia. Hence, we hypothesized that,

$\boldsymbol{H}_{6}$ : Ingratiation is negatively related to eudaimonia at work.

\section{RESEARCH METHODOLOGY}

\subsection{Population and Sample}

For the purpose of reducing the potential bias of the common method (Podsakoff et al., 2003), data were collected in two-time lags (T1 T2). The participants provided their opinion in this study belong to different government institutes of Pakistan. The time difference between the two times lags was two months. The questionnaire was divided into three parts.

At the time lag one, we collected data about demographic information, Ostracism, and sadness. It was distributed among 382 participants of different government sector institutes. During the first time, we received back 348 questionnaires. For administering the second part at time lag two (T2), 348 questionnaires were distributed among the same participants (Keys and codes were utilized to match the T2 part with the T1 part. In this time lag remaining two parts of the questionnaire (parts two and three) were given to employees. Part two was self-rated which contained questions about promotion focus, prevention focus and eudaimonia at work. Part three was peer rated which contained questions about the coworker extra-role and ingratiation behavior. In the second time lag, 296 questionnaires were returned from employees, thus we ended up with a $77.48 \%$ response rate. Furthermore, 5 questionnaires were not complete, so we discarded these questionnaires and only 291 responses were used for data analysis. Data analysis was conducted through PLS software.

\subsection{Instrumentation}

This questionnaire is using a 5-point scale (Likert scale). In this scale, 1 to 5 varies from strongly disagree to strongly agree respectively

- Ostracism: 10-item scale developed by Ferris et al. (2008) was used to measure ostracism at the workplace.

- Sadness: Sadness scale was adapted from Blau (2007).

- Extra role behavior: Extra-role behavior was measured by 20 items scale 
adapted from Turban \& Yan (2016)

- Ingratiation at work: the 5-item scale of Bolino and Turnley (1999) was used to measure ingratiation.

- Promotion and prevention focus: Promotion focus evaluated by 10 -items scale and prevention focus by the 8-items scale of (Lockwood, Jordan, \& Kunda, 2002)

- Eudaimonia at work: Waterman, Schwartz, and Conti (2008) 6-item scale used to measure eudaimonia.

\section{FINDINGS AND RESULTS}

\subsection{Descriptive Statistics}

From 291 respondents 228 were male that constitute $78.4 \%$ of the total amount of respondents and 63 were females that comprised $21.6 \%$ of total respondents. 182 out $(62.5 \%)$ of 291 respondents was lying between the age range of 20-30 year, 102 out (35.1\%) of 291 respondents was lying between the age range of 30-40 year and only 7 out $(2.4 \%)$ of 291 respondents age ranged above 40 years. 160 (55\%) respondents had experienced between 1-5 years, 108 (37.1\%) respondents had experienced between 5-10 years 21 (7.2\%) respondents had experienced between 10-20 years and $2(0.7 \%)$ ) respondents had experienced above 20 years. $24.6 \%$ of data collected from Pakistan Telecommunication limited, 16.9\% from Pakistan International Airlines, 29.9\% from National bank and 26.8\% from Oil Gas Development Company Limited.

For data analysis, we have used PLS software because it is excessive for academic research (Hair, Sarstedt, Pieper, \& Ringle, 2012). Before testing validity, structure paths, and reliability and numerous assumptions relating to multicollinearity and normality were inspected (Hair, Black, Babin, \& Anderson, 2010).

This study uses two-step processes first, assessing the measurement model and secondly structural model assessment for evaluating PSL-SEM results (Hair, Hult, Ringle, \& Sarstedt, 2014).

\subsection{Measurement Model Assessment}

Different researchers are used in the evaluation of item reliability along with determining content validity, internal consistency, discriminant and convergent validity Hair et al., (2014). 


\subsection{Individual Item Reliability:}

It is determined by seeing the outer lading of each item of the construct (Hair et al., 2014). We have been given thumb rule by researchers to measure the item reliability, but it is advised to have it between 0.50 to 0.70 (Hair et al., 2014). The outer loading of concerned data was 0.5 in table 1 so it clearly meets the criteria for item reliability.

\subsection{Internal Consistency Reliability:}

For determining the composite reliability a thumb rule 0.7 or above suggested by Bagozzi and Yi (1988). The composite reliability for every latent variable of this study display in Table 1 . The coefficient of composite reliability ranges from 0.753 to 0.948 of each variable in this study, which shows sufficient consistency, reliability measure (Hair, Ringle, \& Sarstedt, 2011).

\subsection{Convergent Validity}

Ave's assessment was provided by Fornell and Larcker (Fornell \& Larcker, 1981). But Ave must be 0.50 or even more (Chin, 1998). In Table 1 all AVE has a minimum of 0.50 so it is clear that the above data follow this criterion.

\subsection{Discriminant Validity}

It is determined by Fornell and Larcker (1981). Fornell and Larcker suggested that we should have Ave with 0.50 or more. Moreover, the relations between latent variables should be less than the given value of the square root of AVE. Table 2 shows AVE has a value of 0.50 (AVE) and the latent variables are less than the value obtained from the square root of giving AVE value. So, all of our given results find confirmation with respect to discriminant validity.

\begin{tabular}{|c|c|c|c|c|}
\hline Table 1. Cross Loading, CR and ARV \\
\hline Constructs & Item & Loadings & CR & ARV \\
\hline Ostracism at Work & OS1 & 0.762 & 0.948 & 0.648 \\
\hline & OS10 & 0.785 & & \\
\hline & OS2 & 0.777 & & \\
\hline & OS3 & 0.803 & & \\
\hline & OS4 & 0.714 & & \\
\hline & OS5 & 0.827 & & \\
\hline & OS6 & 0.812 & & \\
\hline & OS7 & 0.862 & & \\
\hline
\end{tabular}




\begin{tabular}{|c|c|c|c|c|}
\hline & OS8 & 0.832 & & \\
\hline & OS9 & 0.866 & & \\
\hline \multirow[t]{3}{*}{ Sadness } & SAD1 & 0.504 & 0.762 & 0.529 \\
\hline & SAD2 & 0.908 & & \\
\hline & SAD3 & 0.714 & & \\
\hline \multirow[t]{9}{*}{ Extra role Behaviour } & ERB10 & 0.812 & 0.905 & 0.517 \\
\hline & ERB11 & 0.816 & & \\
\hline & ERB13 & 0.77 & & \\
\hline & ERB14 & 0.684 & & \\
\hline & ERB15 & 0.699 & & \\
\hline & ERB16 & 0.67 & & \\
\hline & ERB5 & 0.656 & & \\
\hline & ERB6 & 0.596 & & \\
\hline & ERB7 & 0.734 & & \\
\hline \multirow[t]{5}{*}{ Ingratiation at work } & ING1 & 0.757 & 0.892 & 0.622 \\
\hline & ING2 & 0.811 & & \\
\hline & ING3 & 0.741 & & \\
\hline & ING4 & 0.865 & & \\
\hline & ING5 & 0.765 & & \\
\hline \multirow[t]{4}{*}{ Eudaimonia at work } & EUD2 & 0.652 & 0.821 & 0.535 \\
\hline & EUD4 & 0.761 & & \\
\hline & EUD5 & 0.788 & & \\
\hline & EUD6 & 0.718 & & \\
\hline \multirow[t]{3}{*}{ Employee Promotion Focus } & POF4 & 0.832 & 0.783 & 0.55 \\
\hline & POF5 & 0.765 & & \\
\hline & POF7 & 0.61 & & \\
\hline \multirow[t]{3}{*}{ Employee Prevention Focus } & PVF4 & 0.662 & 0.753 & 0.506 \\
\hline & PVF5 & 0.805 & 0.948 & 0.648 \\
\hline & PVF6 & 0.659 & & \\
\hline
\end{tabular}

\section{Table 2. Fornell-Larcker Criterion}

\begin{tabular}{|l|c|c|c|c|c|c|c|}
\hline Constructs & $\mathbf{1}$ & $\mathbf{2}$ & $\mathbf{3}$ & $\mathbf{4}$ & $\mathbf{5}$ & $\mathbf{6}$ & $\mathbf{7}$ \\
\hline Employee prevention focus & 0.712 & & & & & & \\
\hline Employee promotion focus & 0.157 & 0.742 & & & & & \\
\hline Eudaimonia at work & 0.126 & 0.31 & 0.732 & & & & \\
\hline Extra role behaviour & 0.219 & 0.404 & 0.443 & 0.719 & & & \\
\hline Ingratiation at work & 0.313 & 0.327 & 0.075 & 0.548 & 0.788 & & \\
\hline Ostracism at work & 0.292 & 0.266 & 0.141 & 0.229 & 0.337 & 0.805 & \\
\hline Sadness & 0.27 & 0.101 & 0.234 & 0.289 & 0.199 & 0.514 & 0.727 \\
\hline
\end{tabular}




\subsection{Structural Model Assessment:}

For the evaluation of the importance of path coefficients standard bootstrapping process including 291 cases and 382 bootstraps has been used in this study Hair et al., (2014). Table 3, Figure 1, explain the complete estimates of the structural model. The result reported that sadness mediates the relationship between ostracism at work and extra-role behavior $(b=0.115, t=4.152, p<0.00)$ therefore $\mathrm{H} 1$ was supported. According to the result, the $\mathrm{H} 2$ was antagonistically supported which purposed that promotion focus moderates between the relationship between sadness and extra-role behavior with $(b=-$ $0.161, \mathrm{t}=2.794, \mathrm{p}<0.03)$. H3 also supported which proposed that sadness mediate the relationship between ostracism at work and ingratiation at work with $(b=0.063, t=1.982$, $\mathrm{p}<0.024)$. Results showed that $\mathrm{H} 4$ was not supported which purposed that prevention focus moderates the relationship between sadness and ingratiation at work with $(b=$ $0.083, \mathrm{t}=0.689, \mathrm{p}<0.245$ ). However, H5 was supported as results showed that there exists a significant (positive) relationship between extra-role behavior and eudaimonia with $(b=0.574, t=9.743, p<0.00)$. Similarly, H6 was also supported which purposed that ingratiation at work negatively associated with eudaimonia at work with $(b=-0.235$, $\mathrm{t}=3.104, \mathrm{p}<0.001)$.

Assessment of R2 value also known as a determinant of coefficient it is a vital criterion in the assessment of variables recommended by PLS-SEM (Hair et al., 2011). Many Scholars claim that the R2 value exhibit variation proportion in variables (dependent) that can be illustrated by at least single or maybe many predictor variables (Elliott \& Woodward, 2007; Hair, Black, Babin, Anderson, \& Tatham, 2006). R2 value level of acceptance is related to the research context place where it is conducted according to Hair et al., (2010). 0.10 R2 is an acceptable value by Falk and Miller (1992). Table 4 shows the $\mathrm{R} 2$ values of this study.

According to the given recommendations of hair et al. (2013), the above study uses Q2 (Cross-Validated-Reduntry-Measures) for the determination of a model's predictive relevance (Hair et al., 2014). Henseler et al (2009) stated that if the value of Q2 in more than zero (0) than the given model constitutes predictive relevance. It is considered a secondary evaluation that is suggested in accordance with the fact that the 
GoF (goodness-off-it) does not prove appropriate for validation of model because it is unable to integrate invalid models from valid models. The Table 5 shows the Q2 results for the study.

\begin{tabular}{|c|c|}
\hline Table 4. R2 value & \\
\hline Constructs & R Square \\
\hline Eudaimonia at work & 0.236 \\
\hline Extra role behavior & 0.257 \\
\hline Ingratiation at work & 0.12 \\
\hline Sadness & 0.264 \\
\hline
\end{tabular}

\begin{tabular}{|l|c|c|c|}
\hline \multicolumn{5}{|l|}{ Table 5. Cross-Validated-Reduntry-Measures } \\
\hline Constructs & SSO & SSE & $\mathbf{Q}^{\mathbf{2}}$ (=1-SSE/SSO) \\
\hline Extra-role behaviour & $2,619.00$ & $2,304.03$ & 0.12 \\
\hline Ingratiation at work & $1,455.00$ & $1,377.08$ & 0.054 \\
\hline
\end{tabular}

\subsection{Testing the Moderation Effect:}

For studying the estimation and assessing the strength of moderation effects of employee's promotion focus for the relationship among sadness and extra-role behavior and between sadness and ingratiation at work, the PLS-SEM product indicator approach was used (Henseler \& Chin, 2010). In reference to the continuity of variables Product indicator approach is utilized in this study (Rigdon, Schumacker, \& Wothke, 1998). Furthermore, Cohen's (1988) directions are used for the determination of moderating effects.

As mention in the $\mathrm{H}_{2}$ promotion focus of employees moderates the relation that exists between sadness and extra-role behavior. According to Table 3 and Figure 1 the interaction terms exhibiting POF*SAD $(b=-0.161, t=2.794, \mathrm{p}<0.03)$ so $\mathrm{H}_{2}$ was antagonistically supported. For plotting the moderating effect of promotion focus on the relation between sadness and extra-role behavior in figure 2 path coefficients knowledge was adopted pursuing the directions mentioned by Aiken, West, and Reno (1991). Figure 2 shows that relationship between sadness and extra-role behavior are stronger when the promotion focus of employee is low and this relationship is weaker when promotion focus is high.

According to $\mathrm{H}_{4}$, the employee prevention focus moderates the relationship 
between sadness and ingratiation at work. In table 3 and figure 1 the interaction terms represent PVF*SAD with $(b=0.083, \mathrm{t}=0.689, \mathrm{p}<0.245)$ was not supported.

Figure 3, explains prevention focus moderating effects on the relationship between sadness and ingratiation at work. The following graph explains the relationship between sadness and ingratiation is stronger when the employee prevention focus is high, and this relationship is weaker when the prevention focus of employees is low.

\begin{tabular}{|c|c|c|c|c|c|c|}
\hline Hypothesis & Relationships & Beta & SE & t-value & P value & Decision \\
\hline $\mathbf{H}_{1}$ & $\begin{array}{l}\text { Ostracism at work -> } \\
\text { Sadness }->\text { Extra role } \\
\text { behaviour }\end{array}$ & 0.115 & 0.028 & 4.152 & 0 & Supported \\
\hline $\mathbf{H}_{2}$ & $\begin{array}{l}\text { SAD*POF -> Extra } \\
\text { role behaviour }\end{array}$ & $\begin{array}{c}- \\
0.161 \\
\end{array}$ & 0.058 & 2.794 & 0.003 & $\begin{array}{c}\text { Antagonistically } \\
\text { supported }\end{array}$ \\
\hline $\mathbf{H}_{3}$ & $\begin{array}{l}\text { Ostracism at work -> } \\
\text { Sadness -> } \\
\text { Ingratiation at work }\end{array}$ & 0.063 & 0.032 & 1.982 & 0.024 & Supported \\
\hline $\mathbf{H}_{4}$ & $\begin{array}{l}\text { SAD*PVF -> } \\
\text { Ingratiation at work }\end{array}$ & 0.083 & 0.121 & 0.689 & 0.245 & Not supported \\
\hline $\mathbf{H}_{5}$ & $\begin{array}{l}\text { Extra role behaviour - } \\
>\text { Eudaimonia at work }\end{array}$ & 0.574 & 0.059 & 9.743 & 0 & Supported \\
\hline $\mathbf{H}_{6}$ & $\begin{array}{l}\text { Ingratiation at work - } \\
>\text { Eudaimonia at work }\end{array}$ & 0.235 & 0.076 & 3.104 & 0.001 & Supported \\
\hline
\end{tabular}




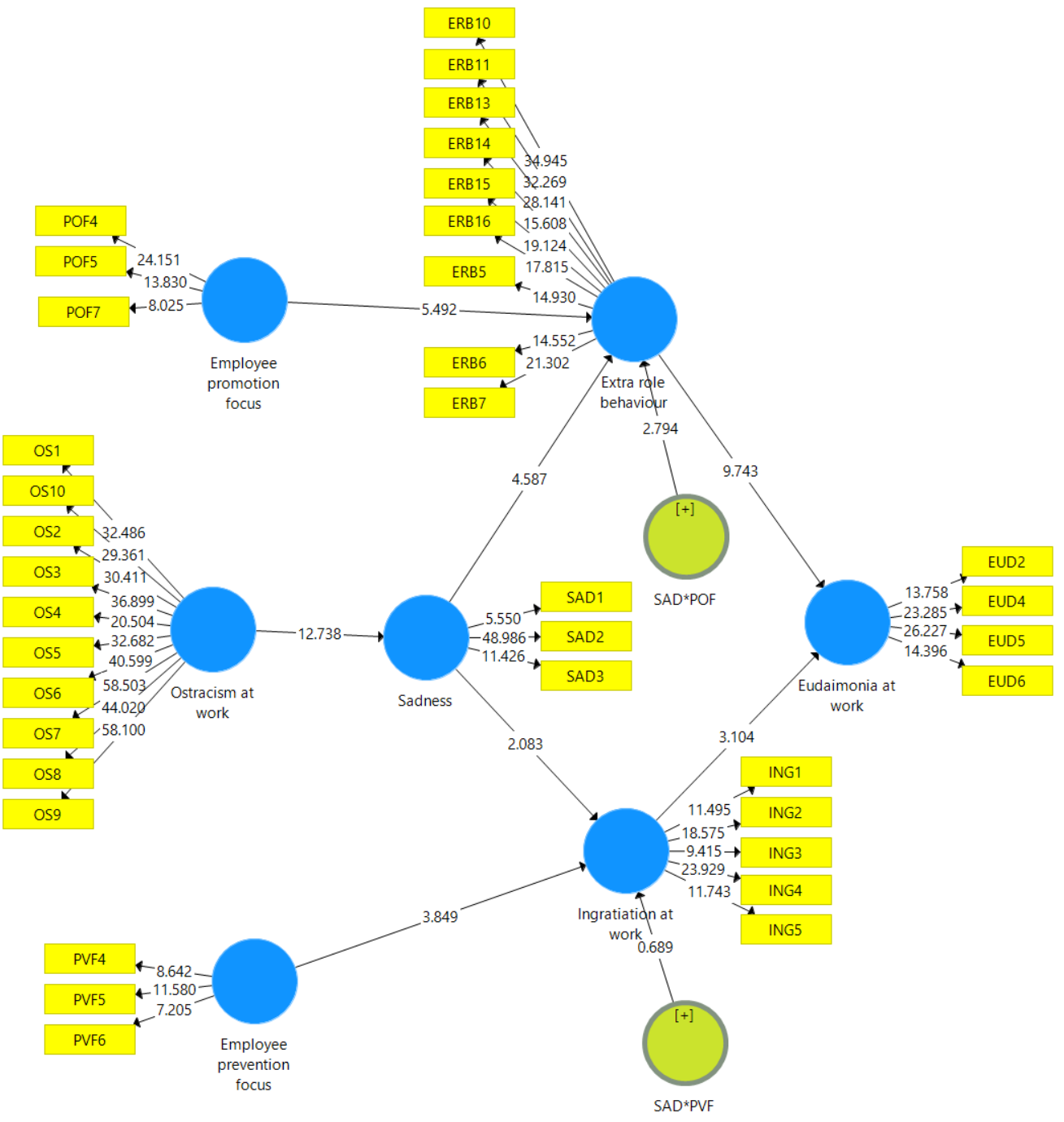

Figure 1: Testing Model 


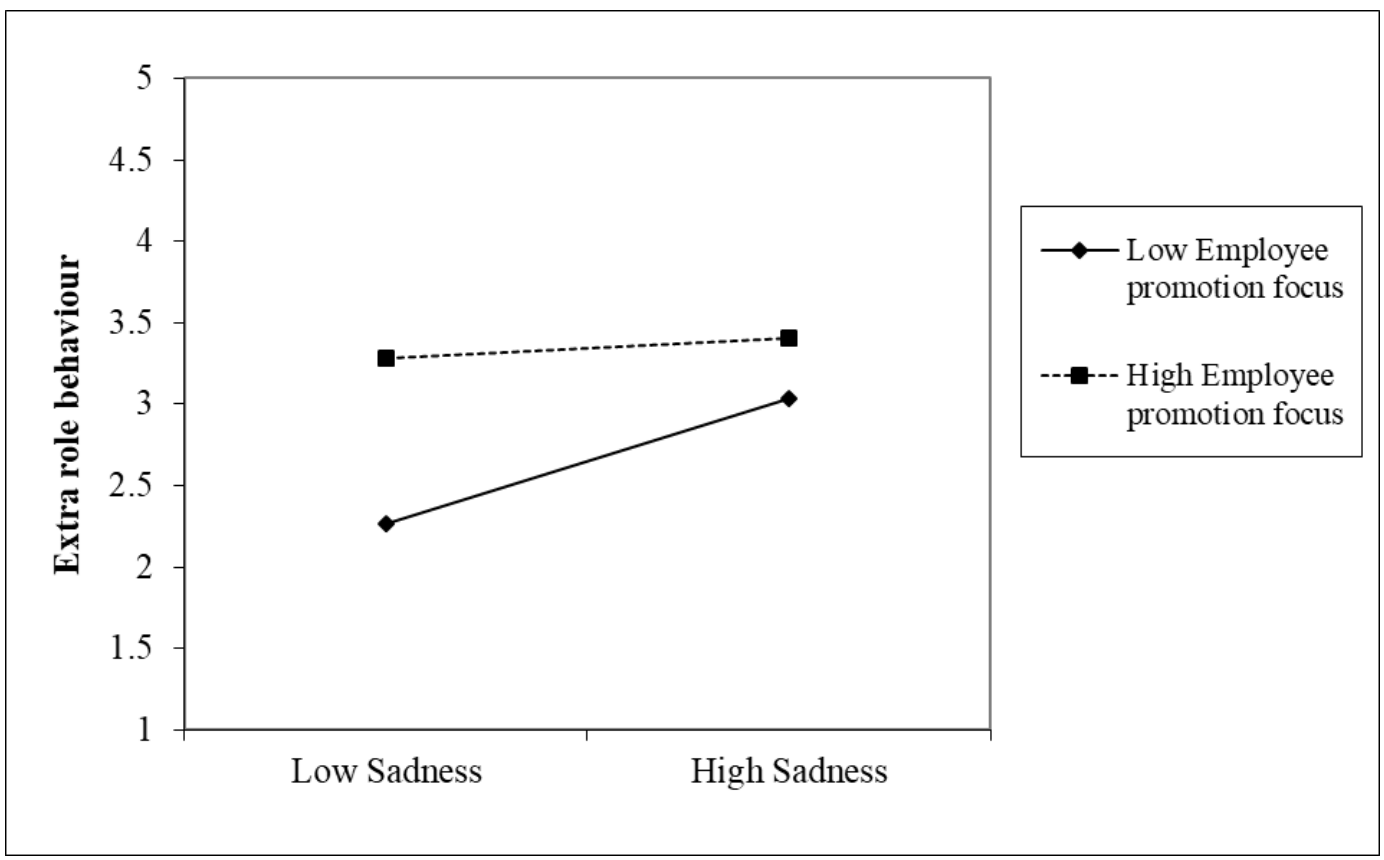

Figure 2. Moderating effect of $P O F * S A D$

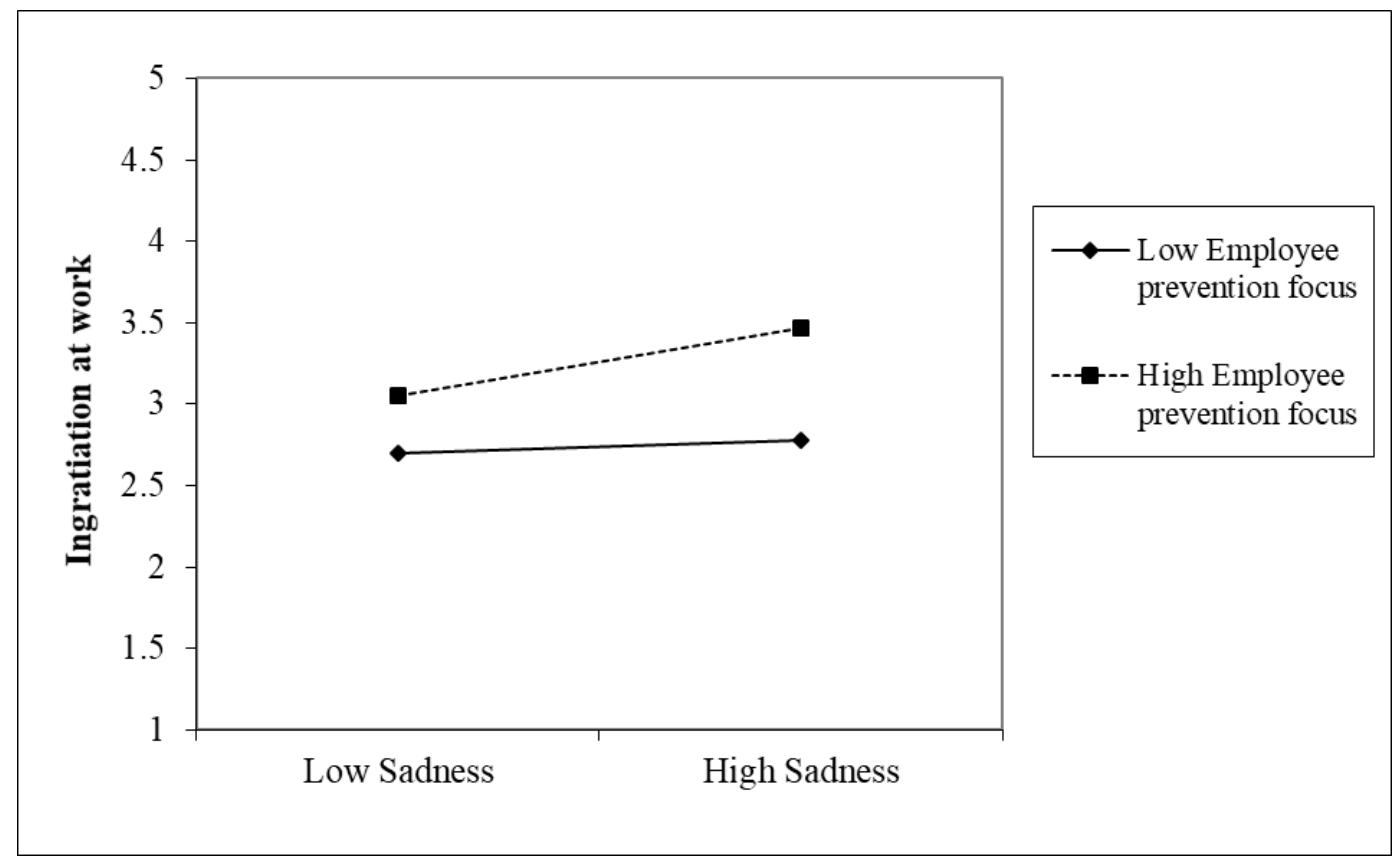

Figure 3. Moderating effect of $P V F * S A D$ 


\section{DISCUSSION}

The major purpose of this study was to check the effect of ostracism at work on extra-role behavior, ingratiation and eudaimonia at work. This research examined the mediating role of sadness between ostracism and extra-role behavior and between ostracism and ingratiation at work. Furthermore, this study tested the moderating role of regulatory focus between sadness and extrarole behavior and between sadness and ingratiation.

The PLS path modeling test determined that sadness does mediate the relationship of ostracism and extra-role behavior. Our finding suggests that sadness stimulates an individual's capability and struggle for goal achievement and motivate grieved individuals to make fruitful efforts to achieve their goals. In other words, sadness caused by rejection strengthens one's abilities and motivates the individuals.

Contrary to our expectations, the results of the study revealed that employee promotion focus antagonistically moderate the relationship between sadness and extrarole behavior. In other words, more the promotion focus, less the chances of conversion of sadness into extra role behavior. The justification behind this can be found in the literature about emotional regulation capability of the individuals (i.e. emotional intelligence). Emotionally intelligent persons have greater control on their nerves. They can be calm and optimistic despite the feeling of deprivation, thus can continue doing more productive work (Miao et al, 2017). Conversely, emotional nonintelligent peoples find it difficult to suppress the negative emotions and unable to exhibit resilience during tough times. In this case, even their promotion regulatory focus does not help them. Third and fourth hypotheses of the study were proven right. Sadness confirmed to mediate between both paths, between ostracism and extra role behavior and between ostracism and ingratiation at work. Our finding reported that when an employee feels sadness due to social loss then they give extra favors and benefits to others to escape themselves from rejection at work because they want to become good in the eyes of others.

The fourth finding of the study involved examining the moderating effect of 
prevention focus between sadness and ingratiation at work. Contrary to our expectations, moderation of prevention focus could not prove significant. Although the direction of the relationship proved positive. The findings of our study suggest that the personality of individuals some time does not affect their behavior. More precisely, According to Tett and Burnett (2003) stated that in particular conditions and situation powerful reward possibilities can remove or fade personality effects.

The fifth objective of the study was to investigate that extra-role behavior is positively related to eudaimonia at work. Our results confirmed a positive significant relationship between extra-role behavior and eudaimonia at work. The justification behind this result is that the employee feels accepted and experience strong and trustworthy relations, leading a placid life when the positive outcomes of extra-role behavior are put in practice in other areas of life.

The sixth objective of the study was to investigate that ingratiation at work is negatively related to eudaimonia at work. The results suggest, in line with our expectations, we found a significant negative relation between extra-role behaviour and eudaimonia at work. As ingratiation is harmful to the personal well-being of the actor because the ingratiator gives extra favors to others for only their personal benefits. Ingratiator does not think about his personal growth and development they only want to reduce or mitigate negative events in their life.

\subsection{Practical Implication}

This study has some practical implication which may be beneficial for the managers of the organization. It is observed that ostracism is a major and important issue but only a little bit of attention is provided to this issue. According to this study, there is some important suggestion for the manager of the organization. The first practical implication is reducing ostracism by taking suitable steps. Williams (1997) proposed that ostracism is more when there are personal differences among individuals. The ostracized individuals end up having low self-esteem. Hence managers must take significant steps to reduce ostracism so that to enhance employees self-esteem. Training sessions must be conducted to guide employees about the harms of ostracism and they must be encouraged to dissolve disputes through discussion and communication. 
Secondly, this study provides great attention to the emotions of employees in the workplace. The organization gives training of emotional intelligence to their employee that helps them regulating and maintaining their emotions for effective and productive usage in improving organizational productivity.

\subsection{Future Recommendations}

Future researchers may collect data from the private sector to generalize the results of the study. Secondly, few personality trait variables such as emotional intelligence may be checked to test the moderating effects between sadness and various behaviors. Future study might take few contextual variable such as political or diversity climate to test the proposed relationships.

\section{REFERENCES}

Aiken, L. S., West, S. G., \& Reno, R. R. (1991). Multiple regression: Testing and interpreting interactions. Sage.Aiken, L., West, S., \& Reno, R. (1991). Multiple regression: Testing and interpreting interactions.

Alnaimi, A. M. M., \& Rjoub, H. (2019). Perceived organizational support, psychological entitlement, and extra-role behavior: The mediating role of knowledge hiding behavior. Journal of Management and Organization. https://doi.org/10.1017/jmo.2019.1

Anderson, J. W. (2009). Organizational Shunning: The Disciplinary Functions of "NonSense." Atlantic Journal of Communication, 17(1), 36-50. https://doi.org/10.1080/15456870802506140

Bagozzi, R. P., \& Yi, Y. (1988). On the evaluation of structural equation models. Journal of the Academy of Marketing Science, 16(1), 74-94. https://doi.org/10.1007/BF02723327

Bilgili, H., Campbell, J. T., O'Leary-Kelly, A., Ellstrand, A. E., \& Johnson, J. L. (2020). The final countdown: Regulatory focus and the phases of CEO retirement. Academy of Management Review, 45(1), 58-84. https://doi.org/10.5465/amr.2016.0455

Blackhart, G. C., Nelson, B. C., Knowles, M. L., \& Baumeister, R. F. (2009). Rejection Elicits Emotional Reactions but Neither Causes Immediate Distress nor Lowers Self-Esteem: A Meta-Analytic Review of 192 Studies on Social Exclusion. Personality and Social Psychology Review, 13(4), 269-309. https://doi.org/10.1177/1088868309346065

Blau, G. (2007). Partially testing a process model for understanding victim responses to an anticipated worksite closure. Journal of Vocational Behavior, 71(3), 401-428. https://doi.org/10.1016/j.jvb.2007.08.005

Bolino, M. C., \& Grant, A. M. (2016). The Bright Side of Being Prosocial at Work, and the Dark Side, Too: A Review and Agenda for Research on Other-Oriented Motives, Behavior, and Impact in Organizations. Academy of Management Annals, 10(1), 599-670. https://doi.org/10.1080/19416520.2016.1153260

Bolino, M. C., \& Turnley, W. H. (1999). Measuring Impression Management in Organizations: A Scale Development Based on the Jones and Pittman Taxonomy. Organizational Research Methods, 2(2), 187-206. 
https://doi.org/10.1177/109442819922005

Bonanno, G. (2009). The other side of sadness: What the new science of bereavement tells us about life after loss.

Bono, J. E., Glomb, T. M., Shen, W., Kim, E., \& Koch, A. J. (2013). Building Positive Resources: Effects of Positive Events and Positive Reflection on Work Stress and Health. Academy of Management Journal, 56(6), 1601-1627. https://doi.org/10.5465/amj.2011.0272

Chang, K., Kuo, C. C., Quinton, S., Lee, I., Cheng, T. C., \& Huang, S. K. (2019). Subordinates' competence: a potential trigger for workplace ostracism. International Journal of Human Resource Management. https://doi.org/10.1080/09585192.2019.1579246

Chen, H., \& Li, W. (2019). Understanding commitment and apathy in is security extra-role behavior from a person-organization fit perspective. Behavior and Information Technology, 38(5), 454-468. https://doi.org/10.1080/0144929X.2018.1539520

Chin, W. W. (1998). The partial least squares approach to structural equation modeling. Modern Methods for Business Research, 295, 295--336.

Chung, Y. W. (2015). The mediating effects of organizational conflict on the relationships between workplace ostracism with in-role behavior and organizational citizenship behavior. International Journal of Conflict Management, 26(4), 366-385. https://doi.org/10.1108/IJCMA-01-2014-0001

Chung, Y. W. (2017). The role of person-organization fit and perceived organizational support in the relationship between workplace ostracism and behavioral outcomes. Australian Journal of Management, 42(2), 328-349. https://doi.org/10.1177/0312896215611190

Clark, M. A., Robertson, M. M., \& Young, S. (2019, February 1). "I feel your pain": A critical review of organizational research on empathy. Journal of Organizational Behavior. John Wiley and Sons Ltd. https://doi.org/10.1002/job.2348

Cohen, J. (1988). Statistical power analysis for the behavioral sciences. HillsUale, NJ: Lawrence Eribaum Associates.

Dotan-Eliaz, O., Sommer, K. L., \& Rubin, Y. S. (2009). Multilingual Groups: Effects of Linguistic Ostracism on Felt Rejection and Anger, Coworker Attraction, Perceived Team Potency, and Creative Performance. Basic and Applied Social Psychology, 31(4), 363-375. https://doi.org/10.1080/01973530903317177

Elliott, A., \& Woodward, W. (2007). Statistical analysis quick reference guidebook: With SPSS examples.

Falk, R., \& Miller, N. (1992). A primer for soft modeling.

Farmer, S. M., Frank Barton, W., Van Dyne, L., \& Kamdar, D. (2015). The contextualized self: How team-member exchange leads to coworker identification and helping OCB. Journal of Applied Psychology, 100(2), 583-595. https://doi.org/10.1037/a0037660

Ferris, D. L., Brown, D. J., Berry, J. W., \& Lian, H. (2008). The Development and Validation of the Workplace Ostracism Scale. Journal of Applied Psychology, 93(6), 1348-1366. https://doi.org/10.1037/a0012743

Fiset, J., \& Bhave, D. P. (2019). Mind Your Language: The Effects of Linguistic Ostracism on Interpersonal Work Behaviors. Journal of Management. https://doi.org/10.1177/0149206319833445

Fornell, C., \& Larcker, D. F. (1981). Structural Equation Models with Unobservable Variables and Measurement Error: Algebra and Statistics. Journal of Marketing Research, 18(3), 382. https://doi.org/10.2307/3150980 
Gray, H. M., Ishii, K., \& Ambady, N. (2011). Misery loves company: When sadness increases the desire for social connectedness. Personality and Social Psychology Bulletin, 37(11), 1438-1448. https://doi.org/10.1177/0146167211420167

Hair, J., Black, W., Babin, B., Anderson, R., \& Tatham, R. (2006). Multivariate Data Analysis (6th ed.). Upper Saddle River, NJ: Pearson Prentice Hall.

Hair, J. F., Black, W. C., Babin, B. J., \& Anderson, R.. (2010). Multivariate Data Analysis, 7th ed., Prentice-Hall, Upper Saddle River, NJ.

Hair, J. F., Hult, G. T. M., Ringle, C. M., \& Sarstedt, M. (2014). A Primer on Partial Least Squares Structural Equation Modeling (PLS-SEM),. Thousand Oaks, CA: Sage Publications.

Hair, J. F., Ringle, C. M., \& Sarstedt, M. (2011). PLS-SEM: Indeed a Silver Bullet. Journal of Marketing Theory and Practice, 19(2), 139-152. https://doi.org/10.2753/MTP1069-6679190202

Hair, J. F., Sarstedt, M., Pieper, T. M., \& Ringle, C. M. (2012). "The use of partial least squares structural equation modeling in strategic management research: a review of past practices and recommendations for future applications",. Long Rang Planing, 45(5-6), 320-340.

Hanke, S., Rohmann, E., \& Förster, J. (2019). Regulatory focus and regulatory mode Keys to narcissists' (lack of) life satisfaction? Personality and Individual Differences, 138, 109-116. https://doi.org/10.1016/j.paid.2018.09.039

Henseler, J., Ringle, C. M., \& Sinkovics, R. R. (2009). The use of partial least squares path modeling in international marketing. Emeraldinsight.Com, 277--319.

Henseler, Jörg, \& Chin, W. W. (2010). A Comparison of Approaches for the Analysis of Interaction Effects Between Latent Variables Using Partial Least Squares Path Modeling. Structural Equation Modeling: A Multidisciplinary Journal, 17(1), 82109. $h$ ttps://doi.org/10.1080/10705510903439003

Henselerko. (2013). Goodness-of-fit indices for partial least squares path modeling. Computational Statistics, 28(2), 565-580. https://doi.org/10.1007/s00180-0120317-1

Higgins, E. T. (1996). The "self digest": Self-knowledge serving self-regulatory functions. Journal of Personality and Social Psychology, 71(6), 1062.

Higgins, E. T. (1997). Beyond pleasure and pain. American Psychologist, 52(12), 1280 1300. https://doi.org/10.1037/0003-066X.52.12.1280

Higgins, E. T. (1998). Regulatory focus as a motivational principle. In Advances in Experimental Social Psychology (Vol. 30, pp. 1-46). https://doi.org/10.1037//0003-066X.55.11.1217

Hitlan, R. T., \& Noel, J. (2009). The influence of workplace exclusion and personality on counterproductive work behaviours: An interactionist perspective. European Journal of Work and Organizational Psychology, 18(4), 477-502. https://doi.org/10.1080/13594320903025028

Jones, R. G., \& Jones, E. E. (1964). Optimum conformity as an ingratiation tactic. Journal of Personality, 32(3), 436-458. https://doi.org/10.1111/j.14676494.1964.tb01351.x

Kark, R., \& VAN DIJK, D. (2019). Keep your head in the clouds and your feet on the ground: A multifocal review of leadership-followership self-regulatory focus. Academy of Management Annals, 13(2), 509-546. https://doi.org/10.5465/annals.2017.0134

Kiazad, K., Kraimer, M. L., \& Seibert, S. E. (2019). More than grateful: How employee 
embeddedness explains the link between psychological contract fulfillment and employee extra-role behavior. Human Relations, 72(8), 1315-1340. https://doi.org/10.1177/0018726718806352

Kim, J. K., LePine, J., Zhang, Z., \& Baer, M. (2019). The Role of Team Context in how Ingratiation Affects Exchange Quality with Targets and Observers. Academy of $\begin{array}{lll}\text { Management } \quad \text { Proceedings, } & 12260 .\end{array}$ https://doi.org/10.5465/ambpp.2019.12260abstract

Kleine, A. K., Rudolph, C. W., \& Zacher, H. (2019). Thriving at work: A meta-analysis. Journal of Organizational Behavior, (April), 1-27. https://doi.org/10.1002/job.2375

Kuykendall, L., Craig, L., \& Tay, L. (2020). Work-contingent self-esteem: A boon or bane for worker well-being? Journal of Organizational Behavior, 41(1), 1-16. https://doi.org/10.1002/job.2408

Levenson, R. W. (1999). The Intrapersonal Functions of Emotion. Cognition \& Emotion, 13(5), 481-504. https://doi.org/10.1080/026999399379159

Li, F., Chen, T., Chen, N. Y. F., Bai, Y., \& Crant, J. M. (2019). Proactive yet reflective? Materializing proactive personality into creativity through job reflective learning and activated positive affective states. Personnel Psychology. https://doi.org/10.1111/peps. 12370

Liberman, N., Molden, D. C., Idson, L. C., \& Higgins, E. T. (2001). Promotion and prevention focus on alternative hypotheses: Implications for attributional functions. Journal of Personality and Social Psychology, 80(1), 5-18. https://doi.org/10.1037/0022-3514.80.1.5

Lichtenthaler, P. W., \& Fischbach, A. (2019). A meta-analysis on promotion- and prevention-focused job crafting. European Journal of Work and Organizational Psychology, 28(1), 30-50. https://doi.org/10.1080/1359432X.2018.1527767

Liden, R. C., \& Mitchell, T. R. (1988). Ingratiatory Behaviors in Organizational Settings. Academy of Management Review, 13(4), 572-587. https://doi.org/10.5465/amr.1988.4307430

Liu, J., Kwan, H. K., Lee, C., \& Hui, C. (2013). Work-to-Family Spillover Effects of Workplace Ostracism: The Role of Work-Home Segmentation Preferences. Human Resource Management, 52(1), 75-93. https://doi.org/10.1002/hrm.21513

Lockwood, P., Jordan, C. H., \& Kunda, Z. (2002). Motivation by positive or negative role models: Regulatory focus determines who will best inspire us. Journal of Personality and Social Psychology, 83(4), 854-864. https://doi.org/10.1037/00223514.83.4.854

Lockwood, P., Marshall, T. C., \& Sadler, P. (2005). Promoting Success or Preventing Failure: Cultural Differences in Motivation by Positive and Negative Role Models. Personality and Social Psychology Bulletin, 31(3), 379-392. https://doi.org/10.1177/0146167204271598

Long, D. M. (2019). Tacticality, Authenticity, or Both? The Ethical Paradox of Actor Ingratiation and Target Trust Reactions. Journal of Business Ethics. https://doi.org/10.1007/s10551-019-04251-3

Mao, Y., He, J., \& Yang, D. (2020). The dark sides of engaging in creative processes: Coworker envy, workplace ostracism, and incivility. Asia Pacific Journal of Management. https://doi.org/10.1007/s10490-020-09707-z

Mccarthy, J. M., Berrin Erdogan, /, \& Bauer, T. N. (2019). An interpersonal perspective of perceived stress: Examining the prosocial coping response patterns of stressed managers. Wiley Online Library, 40(9-10), 1027-1044. https://doi.org/10.1002/job.2406 
McMahan, E. A., \& Estes, D. (2011). Measuring Lay Conceptions of Well-Being: The Beliefs About Well-Being Scale. Journal of Happiness Studies, 12(2), 267-287. https://doi.org/10.1007/s10902-010-9194-x

Megan, Oaten, Williams, K. D., Jones, A., \& Zadro, L. (2008). The Effects of Ostracism on Self-Regulation in the Socially Anxious. Journal of Social and Clinical Psychology, 27(5), 471-504. https://doi.org/10.1521/jscp.2008.27.5.471

Miao, C., Humphrey, R. H., \& Qian, S. (2017). Are the emotionally intelligent good citizens or counterproductive? A meta-analysis of emotional intelligence and its relationships with organizational citizenship behavior and counterproductive work behavior. Personality and Individual Differences, 116, 144--156.

Pihkala, P. (2018). Eco-Anxiety, Tragedy, and Hope: Psychological and Spiritual Dimensions of Climate Change. Zygon, 53(2), 545-569. https://doi.org/10.1111/zygo.12407

Podsakoff, P. M., MacKenzie, S. B., Lee, J. Y., \& Podsakoff, N. P. (2003). Common method biases in behavioral research: A critical review of the literature and recommended remedies. Journal of Applied Psychology, 88, 879.

Rigdon, E. E., Schumacker, E., R., \& Wothke, W. (1998). A comparative review of interaction and nonlinear modeling. Interaction and nonlinear effects in structural equation modeling, 1-16.

Runyan, J. D., Fry, B. N., Steenbergh, T. A., Arbuckle, N. L., Dunbar, K., \& Devers, E. E. (2019). Using experience sampling to examine links between compassion, eudaimonia, and pro-social behavior. Journal of Personality, 87(3), 690-701. https://doi.org/10.1111/jopy.12426

Ryff, C. D., \& Singer, B. H. (2008). Know thyself and become what you are: A eudaimonic approach to psychological well-being. Journal of Happiness Studies, 9(1), 13-39. https://doi.org/10.1007/s10902-006-9019-0

Shah, J., Higgins, T., \& Friedman, R. S. (1998). Performance incentives and means: How regulatory focus influences goal attainment. Journal of Personality and Social Psychology, 74(2), 285-293. https://doi.org/10.1037//0022-3514.74.2.285

Shaheen, S., Bari, M. W., Hameed, F., \& Anwar, M. M. (2019). Organizational cronyism as an antecedent of ingratiation: Mediating role of relational psychological contract. Frontiers in Psychology, 10(JULY). https://doi.org/10.3389/fpsyg.2019.01609

Sirén, C., Fang He, V., Wesemann, H., Jonassen, Z., Grichnik, D., \& von Krogh, G. (2020). Leader Emergence in Nascent Venture Teams: The Critical Roles of Individual Emotion Regulation and Team Emotions. Journal of Management Studies. https://doi.org/10.1111/joms. 12563

Tett, R. P., \& Burnett, D. D. (2003). A personality trait-based interactionist model of job performancer. Journal of Applied Psychology, 88, 500.

Turban, D. B., \& Yan, W. (2016). Relationship of eudaimonia and hedonia with work outcomes. Journal of Managerial Psychology, 31(6), 1006-1020. https://doi.org/10.1108/JMP-07-2015-0271

Tyran, K. L. (2018). The deeper side of sadness at work: Why being sad is not always bad. In Social Functions of Emotion and Talking About Emotion at Work (pp. 191-210).

Warr, P. (2007). Work, happiness, and unhappiness.

Waterman, A. S. (1993). Two conceptions of happiness: Contrasts of personal expressiveness (eudaimonia) and hedonic enjoyment. Journal of Personality and Social Psychology, 64(4), 678. Retrieved from 
http://citeseerx.ist.psu.edu/viewdoc/download?doi=10.1.1.926.830\&rep=rep1\&typ $e=p d f$

Waterman, A. S., Schwartz, S. J., \& Conti, R. (2008). The implications of two conceptions of happiness (hedonic enjoyment and eudaimonia) for the understanding of intrinsic motivation. Journal of Happiness Studies, 9(1), 41-79. https://doi.org/10.1007/s10902-006-9020-7

Weber, L., \& Bauman, C. W. (2019). The cognitive and behavioral impact of promotion and prevention contracts on trust in repeated exchanges. In Academy of Management Journal (Vol. 62, pp. 361-382). Academy of Management. https://doi.org/10.5465/amj.2016.1230

Weinstein, N., \& Ryan, R. M. (2010). When helping helps: Autonomous motivation for prosocial behavior and its influence on well-being for the helper and recipient. Journal of Personality and Social Psychology, 98, 222.

Williams, K., \& Zadro, L. (2005). Ostracism: The indiscriminate early detection system.

Williams, K.D. (2001). Ostracism: The power of silence. New york: Guilford Press.

Williams, Kipling D. (1997). Social Ostracism. In Aversive Interpersonal Behaviors (pp. 133-170). Boston, MA: Springer US. https://doi.org/10.1007/978-1-4757-935437

Wu, L. Z., Yim, F. H. kit, Kwan, H. K., \& Zhang, X. (2012). Coping with workplace ostracism: The roles of ingratiation and political skill in employee psychological distress. Journal of Management Studies, 49(1), 178-199. https://doi.org/10.1111/j.1467-6486.2011.01017.x

Yohana, T., Lubis, M., \& Wibisono, C. (2018). ARELATED SOCIAL SUPPORT OF FAMILIES WITH DEGREES DEPRESSION ON ELDERLY LIVING TOGETHER WITH FAMILY IN WORK AREA OF ROSES.

Zhang, Y., Zhang, Y., Ng, T. W. H., \& Lam, S. S. K. (2019). Promotion- and PreventionFocused Coping: A Meta- Analytic Examination of Regulatory Strategies in the Work Stress Process. Journal of Applied Psychology. https://doi.org/10.1037/ap/0000404

Zhao, J. L., Li, X. H., \& Shields, J. (2019). Managing job burnout: The effects of emotionregulation ability, emotional labor, and positive and negative affect at work. International Journal of Stress Management, 26(3), 315-320. https://doi.org/10.1037/str0000101 